\title{
Proceeding
}

8th INSHS International Christmas Sport Scientific Conference, 5-7 December 2013. International Network of Sport and Health

Science. Szombathely, Hungary

\section{Mountaineering as a specific form of recreation in the late 19th century}

\author{
PAVLINA CHALOUPSKA
}

Department of Leisure and Tourism, Faculty of Informatics and Management, University of Hradec Kralove, Czech Republic.

\begin{abstract}
Chaloupska, P. (2014). Mountaineering as a specific form of recreation in the late 19th century. J. Hum. Sport Exerc., 9(Proc1), pp.S270-S275. Aim of this paper is to characterize mountaineering in the late 19th century as a specific form of recreation on the example of the Prague section of 'Deutschen und Österreichischen Alpenverein' (DuÖAV). Alpinism developed in the second half of the 19th century in the context of the political and economic changes in Central Europe, which also gave rise to many other sports. History of the club and description of the membership and its structure serves as an introduction to the issue. First we describe sources of motivation of members of the section to engage in alpinism. This factor is closely related to the financial demands of this sport at the end of the 19th century. Another essential factor is travelling in relation to destinations of Prague alpinists. The last studied factor is an estimation of time-demandingness in relation to physical activity. This paper is a part of a research focused on establishment and existence of 'Deutschen und Österreichischen Alpenverein' in the Czech Republic before World War II. Key words: CLIMBING, HISTORY, ALPENVEREIN, TRAVELLING.
\end{abstract}

Corresponding author. University of Hradec Kralove, Faculty of Informatics and Management, Department of Leisure and Tourism Czech Republic. Rokitanskeho 62, 50003.

E-mail: pavlina.chaloupska@uhk.cz

8th INSHS International Christmas Sport Scientific Conference, 5-7 December 2013. International Network of Sport and Health Science. Szombathely, Hungary.

JOURNAL OF HUMAN SPORT \& EXERCISE ISSN 1988-5202

(c) Faculty of Education. University of Alicante

doi:10.14198/jhse.2014.9.Proc1.09 


\section{INTRODUCTION}

The origin of mountaineering falls into the period of Humanism and the Renaissance, which brought people closer to nature, naturalists, botanists and geographers pervaded into the mountains and discovered beauty of the surrounding landscape. The beginning of mountaineering dates back to the 1787, when the summit of Mont Blanc was ascended by Horace Benedict Saussure. Since then many people have devoted their life to understanding and conquering mountains. Motives to visit mountains are related to the development of society from historical perspective. Initially, climbing was possible only for wealthy bourgeoisie. That limited the number of climbers. Once the economic and political conditions of other social classes changed, an increasingly higher number of tourists began to flow into the Alps. Since then, from approximately 1870, mountaineering implies characteristics of recreational activity.

German Austrian Alpine Club (DuÖAV) was established in 1874 by unification of German Alpine club (Deutscher Alpenverein - DAV) and Austrian Alpine Club (Österreichischer Alpenverein - ÖAV). The aim of the alpine club was according to its statutes, paragraph 1:" Expanding the knowledge of the Alps, promoting love for them and facilitating travelling in the Alps ". The popularity of this club is illustrated by the fact, that in 1914 the German and Austria club had 102,092 members in 407 sections (Gidel, 2007), 14 of which were in the Czech countries. Already in 1870, one year after the founding of Deutscher Alpenverein, was in Prague established the Prague section DAV, a coalition of hikers and mountaineers, whose aim was to accent the highest peaks in the Alps. Members of the Prague section were mostly citizens of German nationality, who travelled, climbed, published guides, organized meetings and lectures and they also initiated building of many mountain huts and shelters on the ridges in the Eastern Alps. The leading personality was the chairman of the Prague section Johann Stüdl. During his presidency, the Prague section became one of the major centers of alpinism, despite a considerable distance from the region of interests.

In the 80 s of 19th century Prague section was the fifth largest sections of the entire DuÖAV. In the first 10 years there has been a uniform increase in the membership up to 250 . Five years later there were already 415 members and Prague section ranked in third place behind section Austria Wien and a section Munich. Number of members increased up to 482 in 1887. Due to the growing interest about leisure activities in the early 20th century the number of members increased up to 772 in 1914 . The membership structure corresponds to the structure of all other sections DuÖAV. Among the founding members of the Prague section were six businessmen, five lawyers, five manufacturers, four secretaries, three dealers, two pharmacists and two doctors and one professor, engineer, school counselor, director, and photographer. As elsewhere, the largest groups were officials and businessmen. Among the founding members we don't find workers, farmers and local inhabitants of the mountain. "We can say that members DuÖAV came from a well situated bourgeoisie. These professions offer financial options as well as freedom and liberty of movement for the possibility to be interested in a high mountain". (Gidl, 2007, pp.34) From the first years of the existence of Prague section features among members also women. Most of them were wives of Prague climbers, but some of them were also excellent alpinists, par example Marie Eckhert and Hermina Gross Kmoch.

\section{METHODOLOGY}

Research on the topic is based on the historical methods. First the secondary literature sources were researched. The main source of information related to the history and functioning of the Alpine clubs was the publication of Gidle (2007), from which were gained the related statistical data such as the number of 
members DuÖAV. There is almost no contemporary literature or research related to the issues. Kittler (2008) focuses on the development of Sektion Reichenberg DuÖAV and first of all on its personality Rudolf Kauschka. Recently was also held a joint project of Czech members of ÖAV and municipality Kals dedicated to the life of Johan Stüdl, within the articles from Ivo Jirásek were published in the popular climbing journals. Much more information can be found in the historical secondary literature or periodicals such as internal magazine of DuÖAV Mitteilungen, which proceeded from 1875. For the research the primary sources obtained in archives, mainly in the archive of DAV Munich and regional archives in the Czech Republic, were used. The data were critically evaluated and then processed by chronological and retrospective methods. Using the method of probes specific data were identified, such as financial demands related to travel in the 19th century.

\section{RESULTS}

\section{Sources of motivation}

From a historical perspective, it is interesting to track the causes of establishment of sections of DuÖAV in Czech countries. In view of the fact, that the Alps and other high mountains were at least $500 \mathrm{~km}$ away, it is astonishing that so many tourists interested in these sports and recreational activities were associated here. Based on the research one factor appears to be the most significant, and it is the existence of one particular personality. In Prague, for example, it was Johann Stüdl, in Carlsbad Karl Schöttner and in Liberec Joseph A. Kahl. These personalities have been the driving force of the club. They initiated the establishment of the alpine club, construction of huts and they were also actively involved in the activities of central DuÖAV. New members of the community were recruited by promotion in the form of lectures, newspaper articles, and balls, during which the hall was decorated in grand style with alpine themes and participants were dressed in alpine costumes. So the bourgeoisie could create an idea of the beauty of high mountains. Another important factor was the exclusiveness of Alpine club, because members were recruited, as mentioned above, only from well-off middle classes. For adventurers and travelers the club was interesting because of offered discounts on rail travel in Austria. In the 80s of the 19th century this discount was sometimes up to $33 \%{ }^{2}$. Climbing in the Alps at the end of the 19th century offered far more adventure and discovering than it is today. Even among alpinists from Bohemia we can find several firstascent of the Alpine peaks. From the founders of the Prague section it was: Johann Stüdl, who in summer 1869 with his friend made seven first - ascents in the region of Grossglockner. Moritz Umlauf, who made the first- ascent on the top of Nördliche Wildspitze from the glacier Rosenkarferner ${ }^{3}$ in 1880 and Viktor Hecht, who ascended 581 peaks in the years 1867-1894, of which the most important were first ascents on Östliche Marzelspitze ( 3545 ), Suldenjoch ( 3434 ), Hochofenwand ( 3423 ), Liebnerspitze ( 3423 ), Wildgal ( 3272 ), and many others ${ }^{4}$.

\section{The financial demands}

The members of Prague section, as well as those of the entire DuÖAV, paid annual membership contributions. At the time of the establishment of the club the contribution was 0.5 golden thaler, but in 1894 it was 6.75 golden thaler ${ }^{5}$. Another big expense was the rail fare, which made it impossible for many members of the Czech sections to travel to the Alps more than once a year. Price per trip to the Alps, including all discounts was about 15 golden thaler (in 1888 a similar ticket Vienna - Klagenfurt cost 15

\footnotetext{
${ }^{2}$ Festschrift zum 60jährigen Bestehen des Deutschen Alpenvereins Prag, pp. 35

3 Festschrift zum 60jährigen Bestehen des Deutschen Alpenvereins Prag, pp. 118

${ }^{4}$ Festschrift zum 25jährigen Bestehen der Sektion Prag, Praha 1895 pp. 78

5 Annual report 1894 of Prague section, archiv of DAV München, BGS 1 SG/249/2
} 
golden thaler $\left.{ }^{6}\right)$. For accommodation in mountain huts a fee of approximately 0.5 golden thaler was paid per night. The climbers in the 19th century usually used the services of mountain guides. For the highest mountain in the Eastern Alps Großglockner they had to pay 7, 5 golden thaler ${ }^{7}$ in 1870. Proper equipment was essential for each alpinist, it consisted of solid trousers, woolen jacket and wind resistant jacket, socks and studded boots and a hat. For climbing they used climbing shoes. The equipment included $30 \mathrm{~m}$ long hemp rope, ice ax, light, bivouac sack and often photographic material ${ }^{8}$. The above analysis shows that, if climbers wanted to ascent the highest peak in Austria, Grossglockner, they had to pay a total of at least 30 golden thaler plus board. In 1879, the annual cost of living of five-member working class families was around 500 golden thaler out of Prague and 780 golden thaler in Prague. (Efmertová 1998, pp.270). It follows that a single one week trip to the Alps would cost a family one fifteenth of its annual costs. They would have to pay a little less than the existence expenses of a family for one month. Here we find the answer why members of Alpine clubs recruited almost exclusively from the wealthy bourgeoisie.

\section{Travel and the destination}

In the statutes of DuÖAV there is written that "it is necessary to facilitate traveling in the Alps". The sections followed this guideline when they started building mountain huts and touristic paths in the Alps in the late 60 s of 19th century. Each section focused on a particular area, such as the one mountain valley or in the case of large sections the whole mountain group. In this area they usually built a mountain hut and made the surrounding peaks made accessible by marked trails. In the 80s of 19th century Prague section managed the largest area of all sections of DuÖAV; they gradually spread their activity into all major mountain groups in the Eastern Alps. They reached the biggest expansion in 1887. At the end of the 19th century all the sections of DuÖAV operating in the Czech countries built and owned the total of 21 mountain huts. The members oriented majority of their activities in these regions. Active climbers visited also all the important mountain groups in the Alps. First they focused on the highest and most important mountains as Hohe Tauern or Walis Alps in Switzerland, then followed a period of searching technically difficult climbs, for example in the Italian Dolomite and finally they discovered other destinations such as the High Tatra, Himalayas, etc.

In this context it is also interesting to note, what was the form and duration of travel at that time and then later in the 30th of 20thcentury. An example can be found in the almanac of Prague section, which describes the transport from Prague to the hut Neue Prager Hütte. Until the Tauernbahn railroad was opened in 1909, the travel to the hut was very complicated. Southern variant meant to go from Prague to Lienz for 22 to 24 hours, then to Matrei by postal car or horse-coach, which took next 5 hours, then walking for next 7 hours. In Matrei it was necessary to spend the night and afterwards there followed an ascent to the hut Alte Prager Hütte for 8.5 hours - the journey took two days in total. In contrast to this fact, in the 30 s travel from the Czech Republic was at least one day shorter, by fast train through the night to Lienz for 17 hours and then by car to Matrei in one hour and then followed the ascent to the hut ${ }^{9}$.

Travelling in the Alps in 70s of the 19th century was complicated due to non-existing necessary infrastructure, whether it was a rail or road. Tourists were dependent on long time travelling by horsecoach, or on long walks or on horseback. For example, the road to the village of Kals, which is the starting point for the ascent to the Großglockner, was built first in 1927. (Chaloupská, 2012).

\footnotetext{
${ }^{6}$ Mitteilungen 1888, pp. 145

${ }^{7}$ Zeitschrift des Deutschen und Österreichischen Alpenvereins Bd. 01 (1870), pp.70

8100 Jahre Deutscher Alpenverein Sektion Gablonz,

${ }^{9}$ Sektion Prag Nachrichten 1933, archiv DAV München, DAV BGS 1 SG/249/2
} 
Physical stress and time demands

Mountaineering was next to the high financial demands also very time consuming activity. The most active climbers often spent the whole summer season in the Alps. For example, Johann Stüdl in his most successful year 1869 stayed in the Hohe Tauern almost the whole July and September ${ }^{10}$, although as a successful businessman he had to worry about running his company in Prague. Among the climbers we would find far more active alpinists, such as a friend of J.Stüdl Viktor J. Hecht, who in the same year 1869 accomplished 25 ascents ${ }^{11}$. Even nowadays it would be undoubtedly very time consuming, financially and physically demanding action.

We can assume that mountaineering in the late 19th century required an exceptionally high level of physical fitness. Climbers were forced due to lack of infrastructure to walk sometimes several days' arrivals under the peaks. They also often traversed whole difficult mountain ranges without marked and secured trails and supporting huts. An example may be again the trip of Johann Stüdl and Karl Hoffmann started on 9th September 1869, during which they accomplished 7 first- ascents. First they crossed Uttendorf Stubachtal Schneewinkelkopf (3,478 m) Untere Ödenwinkelscharte - Johannisberg (3,460 m) - Hohe Riffel (3338 meters) then descended to Kaprun. On 18.9 they continued by accent to Mittlerer Bärenkopf $(3,356$ m ) - Großer Bärenkopf ( 3,401 m ) Klockerin (3,419 m), and finally to the Großer Wiesbachhorn (3,564 m) 12

\section{CONCLUSION}

In this paper mountaineering was characterized as a recreational activity at the time of establishment of major alpine clubs. The most important factors were detected that contributed to the mass development of the mountaineering in the early 20th century. These results were applied to the example of the Alpine clubs in the Czech countries, which did not differ in their structure, activity and performance from the other sections of DuÖAV. It was shown, that mountaineering was very financially demanding, time consuming and physically challenging activity suitable only for a limited number of members, coming mainly from middle-class bourgeoisie. Other research related to this topic proved high economic influence of climbers on the destinations and also focused on further development of the Alpine clubs in interwar Czechoslovakia.

\section{REFERENCES}

1. 100 Jahre Deutscher Alpenverein Sektion Gablonz.

2. Chaloupská, P. (2011). Činnost pražské sekce DuÖAV (1870-1938) na př́kladu výstavby chat ve východních Alpách, Sciencia Movens, Praha: FTVS.

3. Chaloupská, P. \& Štýrský, J. (2012). History of touristic destination in geographical perspective, Proceedings of the 1st International Conference on Sustainable Tourism and Cultural Heritage (STACH '12), University of Algarve, Faro, Portugal, 2(4), pp.221-225.

4. Efmertová, M. (1998). České země v letech 1848 - 1918. Praha: Libri.

5. Festschrift zum 25 jährigen Bestehen der Sektion Prag, Praha 1895.

6. Festschrift zum 60jährigen Bestehen des Deutschen Alpenvereins Prag: 1870-1930.

7. Festschrift 100 Jahre DAV Sektion Prag.

\footnotetext{
${ }^{10}$ Zeitschrift DAV 1870/71 BandII, pp. 187 -289

${ }^{11}$ Festschrift zum 60jährigen Bestehen des Deutschen Alpenvereins Prag, pp. 108

12 Zeitschrift DAV 1870/71 BandII pp. 187 -289
} 
8. Gidl, A. (2007). Alpenverein. Wien: Bohlau Verlag.

9. Kittler, A. (2008). Rudolf Kauschka 1883-1960, Dresden.

10.Zeitschrift DAV 1870/71 Bd. II.

11.Zeitschrift des Deutschen und Österreichischen Alpenvereins Bd. 01 (1870). 